\title{
Dancing with Rita
}

\author{
Jessica Faleiro
}

Independent Scholar, India

\begin{abstract}
Post-colonial literature from India needs to move away from the tendency to focus on just a British Indian framework and broaden its perspective to include wider frameworks including the Luso-Indian framework. This original 'ghost story' is just one example of Goan Gothic literature that has emerged from the influence of four hundred and fifty-one years of the Portuguese colonial experience in Goa, South India. The author is a Goan migrant and Adult Third Culture Kid, currently living in Goa. This story has been adapted and embellished, based on one that was told to the author by her aunt in Goa over a decade ago.
\end{abstract}

Keywords: Luso-Indian, Goan-Portuguese culture, gothic, cultural identity 
ita hadn't expected to fall in love, but that's what had happened.

It was the end of March, in that period just before the summer heat set in, when the air started to stultify and the scent of frangipani settled low and heavy on the ground.

The Church of St. Cajetan in Ambade, South Goa, had been running a 'secret' weekly dance in their basement hall for two years. The Carmelite nuns had agreed to chaperone the dance only after a brief period of resistance. 'Unmarried boys and girls together? Dancing? Absolutely not! You're only asking for trouble,' said Sister Superior, before finally being convinced by Father Vaz that it was not the worst idea for the village.

Father Vaz was the new parish priest who had been brought in to rejuvenate the flagging numbers of congregates who only seemed to attend Mass when it was Christmas or Feast time. His strategy was to lure in the young people with live music and dancing. It was the roaring Seventies after all. Every Goan Catholic family had at least one singer or musician. There were many local bands eager to establish themselves and willing to play a weekly gig for a pittance. "We're losing youngsters to the latest dance crazes, so we might as well bring the music into the church and let them dance within its walls. That way we can still keep an eye on them." Eventually, even the Bishop agreed that Father Vaz had a point and let the weekly dance continue as an experiment.

Over the previous year they were already seeing teenagers, twenty-somethings and young families travelling longer distances just to attend Sunday mass at their church. Not even the Bishop could argue with the results as the congregation of younger people grew. He let the 'secret-not-so-secret' weekly dance continue while he resigned himself to answering the angry letters of Ambade regulars, mostly stoic widows and elderly couples, who were not happy with the influx of people from outside their village and the image of 'cavorting teenagers' that developed in their imaginations. The dances grew more popular because young men liked the thought of being able to meet potential marriage prospects close up, instead of through heavily chaperoned meetings over a cup of too-milky tea and a plate of 'Parle-G' biscuits in the family sitting-room. Ambade singles began practicing dance moves at home in their bedrooms at night, in the hopes of impressing the prettiest girls and the best dancers among them.

Rita's friend had urged her to go. The dance started around tea-time and lasted only 
a couple of hours, so everyone could get home before twilight. The first time she entered the hall, the stink of feet combined with the smell of damp, hit her. She stood by one of the floor fans scattered around the room to keep the air moving. Scanning the couples crowding the floor, she'd spotted him. He was tall, fair, and had the awkwardness of a young man who was still coming to terms with the growth spurts of his body. Since then, she'd attended five Saturday evenings in a row, and seen him there each time. Each time with a different dancing partner. He seemed to come alive on the dance floor. Yet, even surrounded by people, she could tell that he was very lonely.

Rita watched him swirl the girl with the tight black curls lightly around the floor as if she weighed no more than a feather. She felt a twinge of jealousy that she dismissed as soon as it appeared. She tapped her bright red shoes to the tune of the music, and didn't care whether the other people at the dance were scandalised by her obvious glances in his direction. She felt safe here; invisible. No one came up to her; she was barely noticeable amidst all the beautiful girls around her, who she was convinced were much better dancers.

The band struck up a bold tango and Rita felt her pulse race as she watched the couples move slightly closer to each other. What was it about the tango that stirred one's blood she wondered. From her seat she craned her neck, looking out for his familiar face. The throng on the floor had lessened as not everyone was confident enough to execute the expressive moves of a tango, but she had a suspicion that he would be on the floor. He hadn't sat out a single tango so far.

She jumped as she felt a cold hand on her sleeveless shoulder and looked up. There he was, looking down at her with a serious face and eyes that seemed to burn right into her. He held out his hand in the formal pose requesting a dance. She nodded briefly and put her hand in his before rising from the chair and following him to the centre of the room.

"Alberto. And you are...?"

She looked up at him shyly. "Rita."

He seemed gentle. She imagined that his mother was overprotective and that he preferred reading books to the company of his peers, but on the dance floor he transformed into someone else. His gaze was as confident as his touch as he took her hand firmly in his and placed his other on her waist to guide her. For the length of the tango all she could remember was moving as if she were in a trance; joined together by their hands, their hips and the length of their legs. Rita gasped as he 
manoeuvred her into a step where he ran his calf against hers. It only took a moment, but she felt the heat of every muscle in his lower calf infuse itself into her bare leg. Is this what the nuns had warned them about during every Sunday catechism class she could remember?

He was saying something. She tried to focus.

"What?"

"I said, I haven't seen you here before."

"I'm here every week."

"I would have noticed, I'm sure."

She blushed. She might have misjudged him completely. Or was it the tango that made him so confident?

She gasped again as he pulled her length full against his body and her hand formed the only barrier between their two breasts. She wondered if he'd grown bolder with her because no one had intervened, or because he had also felt something. His heart was beating fast and steady against her palm. She looked up into his face but saw only the focus of preparation for his next move. His thick, dark brows arched gently over deep brown eyes. His skin had an unhealthy pallor and she spotted one red pimple on his chin. She resisted the urge to pop it. His full lips were pursed with determination as he moved her smoothly from one step to the next.

She felt a little disappointed that he wasn't smiling down at her. She looked up again but was barely able to glance at him as he swung her out with his arm and pulled her back in for a turn and a dip. And then she was in the warmth of his arms, as he slowly pulled her up on the final note and held her close enough for her to see the pulse throbbing in is neck.

He was looking at her in a way that made her heart race. It was the look she'd been waiting for, for weeks. In that breathless moment, Rita admitted to herself that she was in love. The surprise revelation hit her hard. With a sinking heart she suddenly realised that he was walking her back to her seat. He reached her chair, bowed before her and said, "Thank you for the dance." She nodded her head graciously, sat down again and watched in dismay as he walked away from her. He took three steps, then seemed to change his mind, and walked back. 
"Rita, I hope you don't find this too forward of me, but would you mind if I kept you company till it was time for you to go home?"

She beamed at him and nodded again. Her luck was changing. She could feel it.

Alberto offered to walk her home, but she refused and he decided not to insist. As he strolled home, hands in his pockets, he wondered why he had lied to her. He had noticed her, from the first time she'd entered the dank, stuffy, basement hall. She was easily the most beautiful girl there and she stood out from all the others. He'd felt his heartbeat quicken and lost his step so noticeably that his partner had complained bitterly when he trod on her toe. It had taken him five Saturdays to scrounge up the courage to ask her to dance with him. He wasn't usually this awkward with women. She was different, and he wished he could put his finger on what it was about her that excited his blood whenever he saw her.

As he got nearer to his home, Alberto's spirit began to fill with dread. He always had to be careful not to let his father know how he was spending his Saturday evenings. As he was creeping past the study to get to his bedroom, he heard his father's voice boom out, "Alberto? Is that you? Home already?" Alberto gave a deep sigh and entered. Vintage tomes lined the walls on either side of the study and five pairs of antelope antlers were mounted behind his father's desk. Alberto had to restrain a snigger every time he entered the study. His father was a wealthy property owner and a corrupt politician, both of which made it affordable and necessary for him to build the image of an erudite litterateur and a successful hunter. These were things society respected, but his father was not.

"Where have you been?"

"I was at the Lotoulim property, minding the builders as you requested, Pai."

"Will they be finished on time?"

"I spoke to the foreman yesterday and told him that he had no choice."

"Good, good. A threat here or there never hurt anybody. Right, son?"

"Yes, Pai."

"Just make sure you stay on top of it. I don't want to have to pay any late interest fees 
to the bank because of your carelessness."

He resented his father's patronising tone, but held his tongue and nodded dumbly. His father slammed the papers in his hand down on his desk. "Remember who you are! I don't want this bloody listlessness that I find in all my workers. It's like a disease! One of you gets it and the whole workforce becomes infected. You are Alberto de Barros Almeida! Descended from the first Almeidas who set foot on Goan soil three hundred years ago."

"And you never let me forget it," muttered Alberto under his breath.

'What did you say?' growled his father in a threatening voice.

"Nothing, Pai."

"That's right. If you want me to beat the apathy and disobedience out of you, you know l'll be more than happy to oblige."

Alberto kept silent, but absent-mindedly stroked his jaw, recalling the last time his father broke it from the beating he gave him after he'd been expelled from an expensive boarding school for fighting.

"Now, get lost and tell the cook to prepare roast chicken tonight."

"Yes, Pai." Alberto shut the study doors behind him and gave a sigh of relief.

His mother had always been the buffer between them. But, after she'd died when he was ten, Don Carmo focused his attention on his son and would brook no dissent. It was his dream for Alberto to assist him with his business, eventually taking over when the time came. All Alberto had ever dreamt about was being a world-class ballroom dancer, ever since his mother had taught him his first Viennese waltz. All that ended when his mother fell ill and died. In his own words, Don Carmo wanted Alberto to "learn the skills of a man who has to make his way in the world by exercising his power and showing off his status, not flirting with women and prancing around at dance parties."

Then Alberto had heard about the secret dance hall in the neighbouring village of Ambade, and realised the dances would happen in the evenings when his father was away and wouldn't notice his son's absence. He walked there and back, taking offroad routes and walking through fields around the village, to ensure he wouldn't be seen by anyone who knew him. 
The first tango, after such a long time of denial, was bittersweet. As much as he felt he belonged the moment he began to move to the music, he was wracked with guilt during the walk home after. But meeting Rita had lessened the darkness within him. He smiled to himself for the first time in ages, as he stepped out of his mud-stained trousers from the long walk home.

Alberto asked Rita to dance the next Saturday and the following one after that. They danced through the sweltering, sweat-soaked summer, getting to know each other a little, and she noticed when he began to dance only with her. That was the way a man let the others know that you were spoken for.

Alberto walked home that evening deep in thought. He was in love with Rita, but he also knew that his father would never let him marry who he wanted, let alone someone without a good dowry or a respectable family name. He had to come up with a good plan. He took out his cotton handkerchief and wiped away the sweat dotting his brow. It was early June and everyone was waiting for the onset of the monsoon to inundate their rice fields and relieve the parched summer earth. In the meantime they were stuck in that purgatory, between seasons, when the air was so thick with humidity that people drove themselves mad waiting for relief from airless nights filled with power cuts, praying to the Virgin Mary for monsoon winds to lash their land.

From the corner of his eye, he spotted something, looked up and stopped in his tracks. In the tree cover lining his path were thousands of fireflies moving around in the last rays of light, doing their mating dance. He remembered a time, not long after his mother's death, when he wandered into the garden with an empty jar to capture a few fireflies and then watched them move around in the bottle, trying to escape. Then he lit a match, dropped it into the jar and watched the fireflies slowly suffocate from the toxic smoke. It brought him great relief.

Later, at Hebron International boarding school, he learned to fight without giving a quarter to the bullies who targeted him. Everyone left him alone after he gained a reputation for fighting with a ring that had a hidden spike that punctured the skin. He got expelled, his father beat him black and blue and paid off the principal of another prestigious boarding school to ensure he would graduate. Nobody knew about the violence, even after he returned and started to learn the basics of his father's business. His father had even managed to cover up that nasty business of the girl he'd impregnated, just to see if he could get away with it. And he had. After his father found out, he never saw or heard from her again and all he got was a new bunch of threats from his father, to cut off his allowance and disown him. He often wished that 
they were more than just empty threats.

But now, there was Rita. When he was with her, he didn't feel rage bubbling up inside him. He felt calm, and loved - the way he'd first felt when his mother taught him to dance; like he belonged somewhere. To him, Rita was the promise of happier times to come. He couldn't risk his father finding out about her. He was worried about what he might do. Elopement was the only way. He knew she'd understand. He'd already told her about his father and his plan for Alberto's life, though hid from her all the stories about his father's brutality.

She agreed on condition that he spoke to her parents, and explained the situation to them, to help them understand why they had to elope.

By the time the rains started, Alberto had planned it all out. The next time he met Rita at the dance, he told her that he'd pick her up from her house the following Saturday, so that he could meet her parents and ask her father for his blessing. He was brimming with confidence as he moved her in a slow tango. Alberto kissed Rita good night on her cheek for the first time. She thrilled as she felt his cold lips against her skin and shivered lightly. The weather had brought in an unusually cold wind the last couple of days.

"Would you like my jumper?" he asked.

"Won't you feel cold?"

He smiled at her. "I haven't felt cold a day since I met you."

She nodded yes, noting his new-found confidence, as Alberto removed his woollen jumper and put it around her shoulders.

"I'll return it to you next week, when you come to the house. Good-night, my love."

It was the first time he'd ever been called that by anyone. He liked it.

Late the following Saturday afternoon, Alberto walked down the oxide red, dirt path, smiling to himself. He re-read the address written on the paper he was holding: House number 54, next to Our Lady of Milagres Chapel, Betalbatim. He saw a man cycling towards him and waved him down. He showed him the piece of paper, then read it aloud when he realised the man was illiterate. 
"Ask the Padrigar there."

Alberto looked up to see where he was pointing, thanked the man and walked towards the entrance of the chapel.

"Good afternoon, Father."

"Good afternoon. Are you lost?" the elderly priest asked, glancing at the paper in Alberto's hand.

"I'm not sure, Father. I'm looking for house number fifty-four."

"Fifty-four? In this area? Are you sure?"

"Yes, why?"

"My chapel is number fifty-three, and the next house down is that one over there. Number fifty-eight."

Alberto followed the priest's finger pointing to a house about a hundred metres away. He frowned in confusion.

"Don't worry son, who are you looking for? Perhaps you got the wrong address, but I know everyone that lives in Betalbatim."

“I'm looking for Rita Rego's house."

"Did you say Rita Rego?”

"Yes father, she's my fiancée."

"The family moved away a long time ago. But, Rita is here."

Alberto looked relieved. "Would you please take me to her?"

The priest nodded mutely at Alberto and motioned to follow. He took him through the chapel entrance, down the centre aisle, through the sacristy and the back door into a grassy courtyard. He stopped in front of a flat cement block lying in the grass and pointed to a gravestone that read: 


$$
\begin{gathered}
\text { Rita Rego } \\
\text { (1951- 1971) }
\end{gathered}
$$

Beloved daughter of Joaquim \& Albertina Rego.

R.I.P.

Alberto gasped when he read the name. "But that's impossible, Father. There must be another Rita Rego in the area, someone you don't know about."

The priest shrugged. "I knew the family well. It's been five years now, but it's still difficult for them. They took Rita's death very hard. It was a shock to us all, her murder."

"Murder...?" Alberto said softly as he turned pale.

“The family knew the boy. They'd been courting, he'd taken her to the Christmas Eve dance at St. Cajetan's in Ambade. She was a very good dancer. That was the last time anyone saw her alive. When they finally found her body, well...a few imagined that it was a lover's tiff...we'll never know." The priest saw the questioning look on Alberto's face. "Some of the men from the village secretly took matters into their own hands before the police could arrest him, you see. The boy never saw the inside of a prison cell." The priest noticed Alberto's pale face and his shortness of breath. He laid a sympathetic hand on Alberto's elbow to steady him, afraid he'd keel over at any second.

"Maybe it's another Rita Rego, after all," the priest said hastily, trying to sound hopeful. "There are so many people coming and going nowadays, I can't keep track of them all." He peered into Alberto's face.

"Your fiancée, did you say? When was the last time you saw her?"

Alberto nodded slowly. "Last Saturday, at the Ambade church dance. That's where I proposed. She said yes. She gave me this address to meet her parents and ask for her father's permission." He looked at the gravestone again and in a bewildered voice said, "I lent her my red jumper."

"Did you say....red jumper?"

"Yes."

The priest went into the sacristy and returned with a red jumper in his hand. 
"Is this yours?"

Alberto grabbed the jumper, saw the familiar label and squeezed it in his hands.

"Where did you find it?"

The priest looked in amazement at Alberto.

"I found this lying on top of Rita's grave, last Sunday after mass."

He was back again the following Saturday. He asked Tania to dance. She had long, lithe legs ending in short, narrow heels that allowed him to pivot her easily around the floor. He was impressed at how easy she was to manoeuvre to the music. He adjusted his body so that she had to lean in a little closer almost touching his chest. The top of Tania's head was just below his nose. He inhaled briefly and the scent reminded him of Rita. The fine hairs on the back of his neck stood up. He glanced up and he saw her then, across the room, sitting in the same corner where he'd first set eyes on her. He twirled Tania around the room, just about managing to keep to the beat while his eyes rested steadily on Rita. She was watching him, expressionless.

He thanked Tania absently at the end of the number, left her standing in the middle of the dance hall and walked over to Rita. He sat next to her in the corner, avoiding the dirty look Tania gave him before she flounced away to get a soft drink.

"I came looking for you."

She smiled at him. "I know."

"I went to the address you gave me and saw your...." He couldn't finish the sentence.

She put her hand on his briefly. "I know. I was watching you from a distance."

He looked around the room. No one was looking their way. "Can they see you?"

"Only if I want them to."

"Who are you?"

She sat silently for a moment, then replied in a voice tinged with an unfathomable 
sadness, "I'm Rosie's friend. She sent me."

Alberto frowned. The last time he'd seen Rosie, she'd told him that she was pregnant with his child. They'd had a loud fight, which his father had overheard and asked him about later.

"Where is she?"

"Don't worry. She's safe now. Your father made sure of that."

Alberto's face blanched. "I didn't know...," he whispered faintly.

Rita smiled gently at him. "You suspected, but you didn't want to know."

He looked down at his feet and nodded.

"Why are you here?" he asked weakly.

She shrugged lightly and smiled at him. "I am your Rita."

He looked out across the floor, then back at her. In that moment, Alberto knew she knew he wanted her, and that there was no turning back for him. 